\title{
TRAINING AND USE OF INTERACTIVE POWER POINTS IN NATURAL EVENT MATERIAL FOR TEACHER PRIMARY SCHOOL AT MUHAMMADIYAH 1 PURWOREJO
}

\section{Titi Anjarini, Galih Yansaputra}

Universitas Muhammadiyah Purworejo

titi_anjarini@yahoo.com

\section{Article History}

accepted 09/07/2018

approved 01/08/2018

published 17/09/2018

\section{Keywords}

Microsoft Power Point Interactive, Nature Event Material

\begin{abstract}
The purpose of community service activity is in the form of training of microsoft power point interactive utilization on natural event material for elementary school at Muhammadiyah 1 Purworejo teachers, among others: (1) teachers become skilled in developing computer-based teaching materials, (2) creating learning innovation in elementary school Muhammadiyah 1 Purworejo, (3) realization of computer-based learning in classroom learning activities, (4) improvement of quality and learning outcomes at Primary School Muhammadiyah 1 Purworejo, (5) scientific publication on utilization of Microsoft Power Point Interactive on Natural Event Material for Teachers SD Muhammadiyah 1 Purworejo, (6) mass media utilization of interactive microsoft power point on the material of natural events for Teachers of SD Muhammadiyah 1 Purworejo. The method applied by the community service activity is in the form of short training using lecture, discussion, question and answer method and the demonstration which was followed by 9 teachers held at SD Muhammadiyah 1 Purworejo which cover the planning, implementation, and production process.
\end{abstract}

Social, Humanities, and Education Studies (SHEs): Conference Series https://jurnal.uns.ac.id/shes

p-ISSN 2620-9284 e-ISSN 2620-9292 


\section{PENDAHULUAN}

Pada dasarnya hidup manusia selalu dipengaruhi oleh perkembangan ilmu pengetahuan dan teknologi. Teknologi mengubah pemikiran manusia, mengubah cara kerja dan cara hidupnya. Salah satunya adalah dengan adanya teknologi pembelajaran tidak terlepas dari empat komponen yang terdiri atas lima komponen yaitu berupa teks, gambar, suara atau audio dan video yang saat ini dapat disajikan dengan menggunakan pemanfaatkan berbagai macam aplikasi yaitu sorfware yang dipergunakan sebagai penyampai pesan maupun informasi yang penting terutama pengetahuan yang disampaikan dari pendidik kepada peserta didik. Aplikasi yang umum kita gunakan yaitu microsorf power point yang dirancang untuk membantu seseorang mempresentasikan materi pelajaran atau bahan presentasi dengan menggunakan program aplikasi microsorf power point yang di komputer sebagai sebuah media pembelajaran dengan menggunakan aplikasi microsorf power point, pendidik dapat menuangkan ide-ide yang berhubungan dengan bidang kerja atau materi pembelajaran yang akan disampaikan hingga menjadi jelas (Marisa, dkk, 7.12: 2011).

\section{METODE}

Kegiatan pengabdian ini dilaksanakan dalam bentuk pelatihan singkat dengan menggunakan metode ceramah, diskusi, tanya jawab dan demonstrasi yang diikuti sebanyak 9 orang guru yang dilaksanakan di SD Muhammadiyah 1 Purworejo yang meliputi tahap perencanaan, pelaksanaan, proses pembuatan produk.

\section{HASIL DAN PEMBAHASAN}

Berdasarkan tanya jawab dan pengamatan langsung selama kegiatan berlangsung, pengabdian ini dapat memberikan hasil sebagai berikut :

1. Menambah wawasan dalam variasi pembelajaran, siswa menjadi lebih antusias dalam pembelajaran.

2. Terwujudnya pembelajaran yang interaktif dengan memanfaatkan power point dalam beberapa kegiatan secara langsung.

3. Menumbuhkan komunikasi antar siswa dan guru.

4. Meningkatkan keterampilan berpikir kritis siswa.

5. Mampu mengatasi permasalahan dalam kehidupan sehari-hari.

6. Memberikan pengalaman belajar yang menyenangkan kepada siswa.

\section{SIMPULAN}

Berdasarkan uraian yanag telah dikemukakan pada bagian sebelumnya, diperoleh kesimpulan bahwa kegiatan pengabdian kepada masyarakat ini dapat:

1. Meningkatkan pengetahuan dan keterampilan guru-guru di SD Muhammadiyah 1 Purworejo tentang pentingnya pemanfaatan teknologi informasi dan komunikasi yaitu melalui pemanfaatan aplikasi microsorf power point.

2. Meningkatkan motivasi guru-guru guru-guru di SD Muhammadiyah 1 Purworejo serta pencapaian yang lebih terbaik kepada para siswa dalam merancang media pembelajaran dengan pemanfaatan aplikasi microsorf power point.

Berdasarkan kepada hasil yang diperoleh maka dapat disarankan beberapa hal sebagai berikut:

1. Berdasarkan permintaan dari peserta, hendaknya kegiatan-kegiatan seperti ini dapat ditingkatkan frekuensi pelaksanaannya.

2. Biaya untuk pelaksanaan kegiatan ini hendaknya lebih ditingkatkan, sehingga dapat melaksanakan kegiatan lebih variatif dan waktu lebih lama. 


\section{DAFTAR PUSTAKA}

Hisnu P, Tantya. (2008). IImu Pengetahuan Sosial 4: SD/MI Kelas IV. Jakarta: Pusat Perbukuan, Departemen Pendidikan Nasional.

Marisa. 2011. Komputer dan Media Pembelajaran. Jakarta: Universitas Terbuka.

Mustofa, Baroroh, K, dan Muhson A. (2012). Pembuatan Media Pembelajaran Interaktif Dengan Microsoft Powerpoint. (Online)

http://staff.uny.ac.id/sites/default/files/pengabdian/mustofa-spd-msc/ppm2012-pembuatan-media-pembelajaran-interaktif-dengan-microsoftpowerpoint.pdf

Nasution. 2005. Teknologi Pendidikan. Jakarta:

Bumi Aksara.Rivai, A dan Sudjana, N. (1990). Media Pengajaran. Bandung: SINAR BARU 